\title{
Contribution of scarred uterus to ruptured uterus in rural Nigeria
}

\author{
Esike Chidi O. U. ${ }^{1 *}$, Aluka Christian O. ${ }^{2}$, Okali Uka K. ${ }^{3}$, Twomey Deirdre E. ${ }^{4}$
}

\author{
${ }^{1}$ Department of Obstetrics and Gynecology, Federal Teaching Hospital, Abakaliki, Ebonyi State, Nigeria \\ ${ }^{2}$ Department of Obstetrics and Gynecology, Abia State University Teaching Hospital, Aba, Abia State, Nigeria \\ ${ }^{3}$ Department of Obstetrics and Gynecology, Federal Medical Center, Umuahia, Abia State, Nigeria \\ ${ }^{4}$ Mile Four Hospital, Abakaliki, Ebonyi State, Nigeria
}

Received: 09 April 2016

Accepted: 07 May 2016

\author{
*Correspondence: \\ Dr. Esike Chidi O. U., \\ E-mail:drchidiesike@yahoo.com
}

Copyright: () the author(s), publisher and licensee Medip Academy. This is an open-access article distributed under the terms of the Creative Commons Attribution Non-Commercial License, which permits unrestricted non-commercial use, distribution, and reproduction in any medium, provided the original work is properly cited.

\begin{abstract}
Background: Ruptured Uterus is one of the worst obstetric catastrophes that cause maternal and perinatal morbidity and mortality. Though surgical incisions on the uterus are thought to contribute to this catastrophe, no work had been done in our environment to find out how scarred uterus had been contributing to uterine rupture in our area of practice hence the need for this work.

Methods: This is a retrospective study involving all the cases of ruptured uterus managed at Mater Misericordiae Hospital, Afikpo in Ebonyi State of Nigeria over 10 years.

Results: During the ten years under review, the incidence of ruptured uterus was $0.66 \%$ or 1 in 151 deliveries. Of the 74 cases of ruptured uterus, 28 or $37.8 \%$ occurred in those with scarred uterus. This translates to 1 uterine rupture caused by scarred uterus in every 2.6 cases of uterine rupture. Previous cesarean section was the commonest scar followed by previous uterine rupture and cornual ectopic pregnancy. There was no rupture from a myomectomy scar. Conclusions: Scarred uterus is a significant cause of uterine rupture, every effort must be made to reduce uterine scars and our women should be encouraged to utilize available health services.
\end{abstract}

Keywords: Scarred uterus, Ruptured uterus, Rural Nigeria

\section{INTRODUCTION}

Ruptured Uterus is one of the worst obstetric catastrophes that can threaten the life of both the mother and the fetus. It contributes significantly to maternal and perinatal mortality and morbidity. ${ }^{1-3}$ In the developed countries where there are adequate and excellent facilities for obstetric care, rupture of the uterus is a rare event. ${ }^{5-7}$ In the developing Countries with poor facilities, ignorance, illiteracy, poverty, high parity, cephalo-pelvic disproportion, prolonged obstructed labor, inappropriate prostaglandin and oxytocin use, application of fundal pressure in labor and during delivery, and an increasing incidence of previous uterine scars, ruptured uterus is a fairly common catastrophe..$^{8-10}$

Though the risk factors of uterine rupture are many and varied in the developing countries, virtually all cases of uterine ruptures occur in the setting of a scarred uterus while in the low income countries, it occurs more in unscarred uterus with the rate of uterine rupture in an unscarred uterus quoted as $0.006 \%$, which increases to $0.5 \%$ following one caesarean section and to $2 \%$ with 2 or more previous caesarean sections. .,6,9-15 $^{-15}$

Despite The numerous predisposing and causation factors of ruptured uterus in our environment like injudicious use of oxytocin, obstetric manipulations such as external cephalic versions, manual removal of placenta, high parity, cephalo-pelvic disproportion and many other prevailing circumstances and factors responsible for ruptured uterus in our environment such as ignorance, poverty, illiteracy, traditional practices, lack of antenatal care and unsupervised deliveries, surgical incisions on the uterus are emerging as major causation factors for ruptured uterus all over the world. ${ }^{16,17}$ Previous caesarean 
section has been recognized as the most important predisposing factor world over for uterine rupture and because the rate of caesarean section is increasing worldwide, the number of mothers with scarred uterus are also increasing. ${ }^{18,19}$ So also is the number of women at risk of uterine rupture. In our environment, with the increasing number of women undergoing myomectomy, more women are exposed to the risk of uterine rupture. In spite of all these and the high prevalence of uterine rupture in our environment, no work had been done to find out how scarred uterus had been contributing to uterine rupture in our area of practice. This is why this work is being undertaken.

\section{METHODS}

All the cases of ruptured uterus managed at Mater Misericordiae Hospital, Afikpo in Ebonyi State of Nigeria over a 10 years period from 2001 to 2011 were got from the Casualty Department, labor ward and labor ward theatre registers. The case notes were retrieved from the records department of the hospital and all the relevant information such as the biodata of the patients like age, parity, occupation, booking status of the patients, the presence of scar on the uterus etc. were extracted and analysed using numbers and percentages.

Mater Misericordiae Hospital where this work was carried out is a secondary/tertiary referral health institution established in 1946 by the Medical Missionary of Mary congregation of the Roman Catholic Mission. It offers primary to tertiary care in obstetrics and gynaecology and is a training health institution approved by the Royal College of Obstetricians and Gynaecologists England, The West African College of Surgeons and the National Postgraduate Medical College of Nigeria for the training of postgraduate doctors in Obstetrics and Gynecology. The hospital also trains general practice doctors at the post graduate level and has a school of nursing and school midwifery for the training of nurses and midwives. It serves the people of Afikpo and the neighbouring towns in Ebonyi state and neighbouring states of Imo, Abia, Cross River states of Nigeria with referrals also from other parts of the Country.

\section{RESULTS}

During the ten years under review (from 2001 - 2011) there were a total of 77 cases of ruptured uterus out of which 74 or $96.1 \%$ case notes were found and used for the study. There were a total of 11,139 deliveries over the ten year period giving the incidence of ruptured uterus as $0.66 \%$ or 1 in 151 deliveries. Of the 74 cases of ruptured uterus as seen in table II and figure 1, 46 or $62.8 \%$ occurred in women with intact uterus while 28 or $37.8 \%$ occurred in those with scarred uterus. This gives an incidence of one uterine rupture from a scarred uterus in every 398 deliveries. In terms of the proportion of uterine rupture caused by scarred uterus to one caused by unscarred uterus, there was one uterine rupture caused by scarred uterus in every 2.6 cases of uterine rupture.

Table 1: Socio-demographic characteristics.

\begin{tabular}{|c|c|}
\hline Parameter & No $(\%)$ \\
\hline Age (Years) & No (\%) \\
\hline $20-25$ & $7(25)$ \\
\hline $26-30$ & $12(42.9)$ \\
\hline $31-35$ & $6(21.4)$ \\
\hline $36-40$ & $3(10.9)$ \\
\hline Total & $28(100 \%)$ \\
\hline Booking status & No $(\%)$ \\
\hline Booked & $20(71.4)$ \\
\hline Unbooked & $8(28.6)$ \\
\hline Total & $28(100)$ \\
\hline \multicolumn{2}{|l|}{ Parity } \\
\hline 1 & $12(42.9)$ \\
\hline $2-4$ & 11(39.3) \\
\hline$\geq 5$ & $5(17.9)$ \\
\hline Total & $28(100)$ \\
\hline Occupation & No (\%) \\
\hline Farmer & $18(72)$ \\
\hline Housewives & $6(21.4)$ \\
\hline Trading/Business & $3(10.7)$ \\
\hline Civil servants & $1(3.6)$ \\
\hline Total & $28(100)$ \\
\hline Social class & No $(\%)$ \\
\hline 1 & - \\
\hline 2 & $1(3.6)$ \\
\hline 3 & $2((7.6)$ \\
\hline 4 & $9(32.1)$ \\
\hline 5 & $16(57.1)$ \\
\hline Total & $28(100)$ \\
\hline
\end{tabular}

Table 2: Type of uterus that ruptured.

\begin{tabular}{|llll|}
\hline $\begin{array}{l}\text { Type of uterus } \\
\text { that ruptured }\end{array}$ & $\begin{array}{l}\text { Intact } \\
\text { uterus }\end{array}$ & $\begin{array}{l}\text { Scarred } \\
\text { uterus }\end{array}$ & Total \\
\hline No (\%) & $46(62.8)$ & $28(37.8)$ & $74(100 \%)$ \\
\hline
\end{tabular}

Of these 28 patients with scarred uterus who had uterine rupture, majority 12 or $42.9 \%$ as seen in table one were in the 26-30 year old age bracket. Majority 18 (72\%) were farmers followed by housewives 6 (21.4\%). Also majority, $25(89.3 \%)$ were in social classes 4 and 5 . Eighteen or $72 \%$ of these women were booked. The majority $12(42.9 \%)$ were Para one, followed by 11 $(39.3 \%)$ in the $2-4$ parity group while $5(17.8 \%)$ were in the Para 5 or above group.

Majority of the scarred uterus $24(85.7 \%)$ as seen in table III and figure 2, was due to previous cesarean section, one $(3.6 \%)$ of which was the classical type, while 2 $(7.2 \%)$ were due to previous uterine rupture and one $(3.6 \%)$ was a surgery for cornual ectopic pregnancy. The rupture in the previous classical caesarean section occurred at 22 weeks. Of the rupture from previous 
caesarean sections, 21 or $87.5 \%$ of all uterine ruptures from previous caesarean sections or $75 \%$ were from one previous caesarean section, two or $8.3 \%$ were from 2 previous caesarean sections and one or $4.2 \%$ from 3 previous caesarean sections . None of the rupture was due to Myomectomy or other causes of uterine scar. Majority of the rupture $27(96.4 \%)$ was anterior uterine rupture (Table 4). Thirteen or $46.4 \%$ of the uterine ruptures occurred at the old site of scars as dehiscence while 15 or $53.6 \%$ occurred at new or fresh sites in the uterus (Table $5)$.

Table 3: Cause of scar to the uterus.

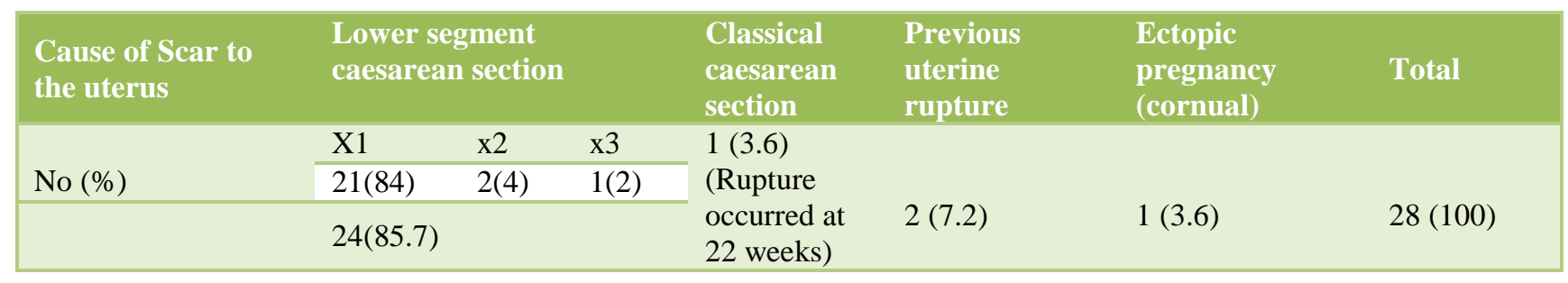

Table 4: Position of rupture.

\begin{tabular}{|llll|}
$\begin{array}{l}\text { Position of } \\
\text { rupture }\end{array}$ & Anterior & Posterior & Total \\
\hline No (\%) & $27(96.4)$ & $1(3.6)$ & $28(100)$ \\
\hline
\end{tabular}

Table 5: Site of rupture.

\begin{tabular}{|llll|}
\hline $\begin{array}{l}\text { Site of } \\
\text { rupture }\end{array}$ & $\begin{array}{l}\text { Old site } \\
\text { (Dehiscence) }\end{array}$ & $\begin{array}{l}\text { Fresh or } \\
\text { new site }\end{array}$ & Total \\
\hline No (\%) & $13(46.4)$ & $15(53.6 \%)$ & $28(100)$ \\
\hline
\end{tabular}

Table 6: Type of repair.

\begin{tabular}{|llll|}
\hline $\begin{array}{l}\text { Type of } \\
\text { Repair }\end{array}$ & $\begin{array}{l}\text { Repair } \\
\text { alone }\end{array}$ & $\begin{array}{l}\text { Repair }+ \\
\text { Bilateral } \\
\text { tulbal } \\
\text { ligation }\end{array}$ & Hysterectomy \\
\hline No (\%) & $19(67.9)$ & $6(21.4)$ & $1(3.6)$ \\
\hline
\end{tabular}

Table 7: Maternal outcome.

\begin{tabular}{|llll|}
\hline $\begin{array}{l}\text { Maternal } \\
\text { outcome }\end{array}$ & Alive & Dead & MMIR \\
\hline No(\%) & $27(96.4)$ & $1(3.6)$ & 3,571 per 100,000 \\
\hline
\end{tabular}

Table 8: Fetal outcome.

\begin{tabular}{|lllll|}
$\begin{array}{l}\text { Fetal } \\
\text { outcome }\end{array}$ & Alive & Dead & $\begin{array}{l}\text { Perinatal } \\
\text { mortality }\end{array}$ & $\begin{array}{l}\text { Total } \\
\text { rate }\end{array}$ \\
No (\%) & $8(28.6)$ & 20(71.4) & $\begin{array}{l}714 \\
1000\end{array}$ & per 28(100) \\
& & & & \\
\hline
\end{tabular}

Nineteen or $67.9 \%$ of the ruptures were treated by repair alone, 6 or $21.4 \%$ by repair and bilateral tubal ligation. Hysterectomy was the mode of treatment in only one or $3.6 \%$ of the cases (Table 6). Twenty seven or $96.4 \%$ of the mothers were alive while one mother died giving a maternal mortality ratio of 3,571 per 100,000 births. Only 8 or $28.6 \%$ of the babies were alive (Table 8 ) giving a perinatal mortality rate of $714 / 1000$ births. Of these, only 3 or $37.5 \%$ had an Apgar score of 8-10 in one minutes while $3(37.5 \%)$ had a score of 5-7 in the first minute and $2(25 \%)$ an Apgar score of less than 5 in the first minute (Table 7).

Table 9: Apgar score of live babies.

\begin{tabular}{|lllll|}
\hline $\begin{array}{l}\text { Apgar } \\
\text { Score }\end{array}$ & $8-10$ & $5-7$ & $<5$ & Total \\
\hline No $(\%)$ & $3(37.5)$ & $3(37.5)$ & $2(25)$ & $8(100)$ \\
\hline
\end{tabular}

\section{DISCUSSION}

Majority of our patients as seen in table I, 19 or $67.9 \%$ were in the 20-30 year age bracket and $12(42.9 \%)$ were para one and majority 18 or $72 \%$ were booked while 7 (28\%) were unbooked. This is in contradistinction to some other studies were majority of their patients were not booked. ${ }^{20}$ The majority of our patients who had scarred uterus being booked could be because they were counselled in their previous deliveries after the scar to book in subsequent pregnancies or that they booked in their index pregnancy in our center but when counselled on the need for surgery went elsewhere to deliver coming to us again only when complications had arisen.

In our study, a significant percentage of ruptured uterus 28 or $37.8 \%$, though less than the majority, was contributed to by scarred uterus. Though a lesser percentage of uterine rupture in this study was caused by scarred uterus this is very significant as it translates to every 1 in 2.6 cases of uterine rupture being caused by a scarred uterus. This agrees with the assertion that the most important risk factor to uterine rupture is the presence of a scarred uterus. ${ }^{18,19}$ The contribution of scarred uterus to uterine rupture is quite significant in this study and is likely to be on the rise especially in our 
environment given the increased rate of caesarean section and the known aversion of our women to abdominal delivery. ${ }^{21}$ Again, the unhygienic and septic environment of traditional birth attendants and other quacks our women first go to for delivery before resorting to hospitals for surgery when complications arise may reduce wound strength and also contribute to this tragedy. Our rate of scarred uterus contributing to uterine rupture is lower than in the work of Ibekwe in Enugu in the same south Eastern Nigeria where uterine rupture contributed to $56.5 \%$ to ruptured uterus in his Center. ${ }^{20}$ This could be because in his Center, a big Teaching hospital, delays caused by beaurocracy and getting different cadres of health workers to work fast and seamlessly in emergencies.

Majority of the scarred uterus contributing to uterine rupture, $25(89.3 \%)$ table III was by previous cesarean sections. Twenty one $(84 \%)$ of these was from one previous cesarean section, $2(4 \%)$ from 2 previous and one $(2 \%)$ from 3 previous cesarean sections. One was from a classical cesarean section and the rupture occurred at 22 weeks gestation. The fact that previous cesarean section scar is a major cause of uterine rupture in our environment is not surprising. This is because, lots of studies had shown the aversion of our women to abdominal delivery and that these women will go to any length, including unsupervised deliveries to achieve their long-held and cherished dreams of vaginal delivery which is the culturally accepted mode of delivery. ${ }^{20}$ Also, most cesarean sections in the developing Countries are done after neglected and infected obstructed labor and often in the presence of overwhelming infections thus making uterine scars suspect and most likely unable to stand the stress of vaginal birth. Again the increasing economic hardship and high cost of medicare in our environment scare away people that need the services of hospitals most. These are compounded by the activities of quacks, spiritualists and modern Pentecostal churches that entice pregnant women at high risk away from hospitals.

Previous caesarean sections, had been noted as both a predisposing and and etiological factor in uterine rupture especially in our environment. ${ }^{18,19,22}$

Obiechina et al in Nnewi South Eastern Nigeria and Kidanto in Muhambili Tanzania found caesarean section as the commonest cause of ruptured uterus in their works. $^{7,24}$

Majority of the uterine rupture in our study were anteriorly located. This agrees with other workers. ${ }^{4}$ Majority of the uterine rupture in our study, 19 or $67.9 \%$ were treated by repair alone while 6 or $21.4 \%$ were by repair and bilateral tubal ligation and one by hysterectomy. This is in contradistinction to some other works where majority of their patients were treated by hysterectomy. ${ }^{20}$ This may be due to the fact that a significant number of the uterine ruptures in our study 13
(46.4\%) were dehiscence of the old scar sites that were amenable to repair with or without bilateral tubal ligation. Moreover, our more conservative management could have been in consideration of the high premium our study population placed on their womb and to encourage them to keep adopting hospital delivery. Here a woman whose reproductive career is prematurely terminated by hysterectomy faces a lot of humiliation in the society because of her inability to bear children for her husband and risks her husband marrying another woman or her being totally chased out from her matrimonial home. Also abrupt cessation of menses in a young woman can be worrisome as it can be taken to be a loss of womanhood.

Majority of mothers 27 or $96.4 \%$ were alive in our series with only one maternal death (a maternal mortality ratio of 36 per 100,000 ) or $3.6 \%$. This is in contradistinction to other works were uterine rupture contributed significantly to maternal mortality. ${ }^{21,22,24}$ Our low maternal mortality figure could be due to a significant number of our cases being due to uterine dehiscence and the fact that majority of our patients were booked and managed in the hospital and were intensively monitored and cared for having had previous scar to their uterus.

However, only 8 or $28.6 \%$ of the babies in our study were alive. This high perinatal death of 20 or $71.4 \%$ (perinatal mortality rate of 714 per 1000) is very high and saddening. This high fetal wastage is in keeping with known facts that uterine rupture is more severe on the fetus than the mother. ${ }^{2,22}$ Also contributory could be the earlier mentioned aversion of our women to cesarean section which could have made them seek delivery elsewhere on being counselled for cesarean section only to come to the hospital when complications like uterine rupture had occurred and their babies already dead. The high fetal wastage of $71.4 \%$ or perinatal mortality rate of 714 per 1000 in our study is higher than the 6 per 1000 got by Obiechina et al at Nnewi. ${ }^{7}$ This may be due to the fact that they monitored their patients more closely and had better neonatal intensive care unit. Our fetal wastage rate however is lower than the $100 \%$ fetal mortality got by Aliyu et al in Bauchi, 913 per 1000 got by Ibekwe in Enugu, and $86.3 \%$ by Dattijo et al in Azare all in Nigeria. ${ }^{1,22,24}$ Our perinatal mortality rate being lower than theirs could be because $46.4 \%$ of our uterine rupture were dehiscence. It could also be due to closer monitoring of our patient majority of whom were booked and consequent earlier operative interventions. Also our neonatal intensive care could also be more effective than theirs.

Two (25\%) of the surviving babies in our study had an apgar of less than 5 in one minute. This severe asphyxiation of these babies could lead to life-long adverse consequences. Every effort must therefore be made to make sure that this does not happen in future, 
We consider it worthy of mention that there were no uterine rupture that occurred as a result of a scar on the uterus because of myomectomy. This is more so because myomectomy is a fairly common gynaecological surgery in our environment. This is in contrast to other works where uterine scar from myomectomy had contributed to uterine rupture. $^{25}$ Though it has been said that the incidence of uterine rupture following myomectomy is less well documented and evidence in this area remains limited due to its rarity, uterine rupture after abdominal myomectomy is uncommon with the incidence reported in literature to range from 0.24 to5.3\%. ${ }^{26}$

\section{CONCLUSION}

Ruptured uterus, though a preventable obstetric disaster, is causing a lot of avoidable fetal and maternal morbidity and mortality as well as exerting a very big strain on the human and material resources in our already resourceconstrained countries. This study had shown that scared uterus especially from previous caesarean section scar is a major contributor to uterine rupture with the subsequent maternal and perinatal morbidity and mortality. If we are to make any significant headway in reducing maternal and perinatal mortality, we must address ways of reducing the soaring caesarean section rates and the entrenched aversion of our women to abdominal delivery while encouraging them to utilize available maternity services.

\section{Funding: No funding sources}

Conflict of interest: None declared

Ethical approval: The study was approved by the Institutional Ethics Committee

\section{REFERENCES}

1. Dattijo LM, Umar NI, Yusuf BM. Ruptured uterus in Azare North Eastern Nigeria.Jos Journal of Medicine. 2011;5(2).

2. Danso KA. Ruptured Uterus. In: Comprehensive Obstetrics in the tropics, First edition, Kwawukume EY, Emuveyan EE (Eds), Asante \& Hittscher Printing Press Limited, Dansoman. 2002:86-92.

3. Odusoga OL, Adefuye PO, Olayede OA, Fakoya TA, Olatunji AO Uterine rupture: a major contributor to obstetric morbidity in sagamu. Trop J Obstet Gynnecol. 2003;20(2):137-40.

4. Lawson JB. Sequelae of Obstructed Labour. In: Lawson JB, steward DB (eds) Obstetrics and Gynecology in the Tropics and Developing Countries London, Arnold; 1967:203-210.

5. Nahum G, Pham K. Uterine rupture in pregnancy. Medscape, 2012, http:// reference. Medscape.com/article/275854- overview.

6. Hofmeyer GJ, Say L, Gulmezoglu AM. WHO systemic review of maternal mortality and morbidity: the prevalence of uterine rupture. BJOG. 2005;112(9):1221-28.
7. Obiechina N, Eleje GU. an analysis of uterine rupture at the Nnamdi Azikiwe University Teaching Hospital, Nnewi, Southeast Nigeria. Niger J Clin Pract. 2012;15:448-52.

8. Pan HS, Huang LW, Hwang JL, Lee CY, Tsai YL, Cheng WC. Uterine rupture in an unscarred uterus after application of fundal pressure. Reprod Med. 2002;47:1044-6

9. Souza JP, Cecatti JG, Parpinelli MA, d Sousa MH, Seruya SJ. Systematic review of near miss maternal morbidity, Cad Saude Publica. 2006;22:255-64.

10. Van Den Akker T, Beatrice M, James I, van Roomalen J. Using audits to reduce the incidence of uterine rupture in a Malawian district hospital. Int $\mathbf{J}$ Obstet Gynecol. 2009;107(3):289-94.

11. Ronsmans C, Fillipi V. Beyond the numbers, reviewing maternal deaths and complications to make pregnancy safer: reviewing severe maternal morbidity: learning from women who survive lifethreatening complications. 2004. Geneva: world Health Organisation.

12. Kwee A, Bots ML, Visser GH, Bruinse HW. Obstetric management and outcome of pregnancy in women with a history of caesarean section in the Netherlands. Eur J Obstet Gynaecol Reprod Biol. 2007;132:171-6.

13. Kaczmarczyk M, Sparen P, Terry P, Cnattingiuss: Risk factors for uterine rupture and neonatal consequences of uterine rupture: a population-based study of successive pregnancies in Sweden. BJOG. 2007;114(10):1208-14.

14. Mukasa PK, Kabakyenga J, Senkungu JK, Ngonzi J, Kyalimpa M, Roomalen van J. Uterine rupture in a Teaching Hospital in Mbarara, Western Ugandaunmatched case-control study. Reproductive Health. 2013;10:29.

15. Qublan HS, Tahat Y. Multiple Caeasrean section: the impact on maternal and fetal outcome. Saudi Medical Journal. 2006;27(2):210-4.

16. Roberts OA, Ekele BA. Ruptured uterus: halting the scourge. Trop J Obstet Gynaecol. 2002;19(1):1-3.

17. Audu LR, Ekele BA. A ten year review of maternal mortality in Sokoto, Northern Nigeria. West Afr J Med. 2002;21:74-6.

18. Kurdoglu M, Kolusari A, Yildizhan R, Adali E. Delayed diagnosis of an atypical rupture of an unscarred uterus due to assisted fundal pressure: a case report. Cases J. 2009;2:7966.

19. Al-Zirqi I, Stray-Pedersen B, Forsen L, Vangen S. Risk of uterine rupture after previous caesarean section. BJOG. 2010;117(7):809-20.

20. Ibekwe PC. Ruptured uterus in Enugu, Nigeria. PHMJ. 2008;2(2)136-9.

21. Esike O, Onoh C, Anozie B, Umeora U, Aluka O, Twomey E. Vaginal Birth after one Cesarean section- Ten Years Experience In A South Eastern Nigerian Hospital. Open Journal Of Obstetrics and Gynecology. 2016,6:240-5.

22. Umeora OUJ, Ejikeme BN, Egwuatu VE. Contribution of ruptured uterus to maternal mortality 
in rural south Eastern Nigeria. Trop J Obstet Gynaecol. 2005;23(2):184-8.

23. Kidanto HL, Mwampagatwa I. Uterine rupture: a retrospective analysis of causes, complications and management outcome at Muhimbili National Hospital in Dares Salam Tanzania. Tanzanian Journal of Health Research. 2012;14(3).

24. Aliyu LD, Elnafaty AU, Kadas SA, Dattijo LM,Aminu BM. Uterine rupture an obstetric catastrophy: Incidence risk factors management at
Tafawa Balewa Teaching Hospital Bauchi Nigeria. Trop J Obstet Gynecol. 2012;29(1).

25. Sutton C, Standen P, Acton J, Griffen C. Spontaneous uterine rupture in a preterm pregnancy following myomectomy. Case reports in Obstetrics and Gynecology. 2016, Article ID 6195621, 4 pages.

26. Bernardi TS, Radosa PM, Weisheit A. Laparoscopic myomectomy: a 6-year follow-up single-center cohort analysis of fertility and obstetric outcome measures. Archives of Gynecology and obstetrics, 2014;29(1):87-91.

Cite this article as: Esike Chidi OU, Aluka Christian O, Okali Uka K, Twomey Deirdre E. Contribution of scarred uterus to ruptured uterus in rural Nigeria. Int J Reprod Contracept Obstet Gynecol 2016;5:1790-5. 